\title{
Kowenanty w warunkach emisji długu przez przedsiębiorstwa a ochrona obligatariuszy
}

\begin{abstract}
Use of covenants in corporate debt and bondholders' protection: The article addresses the issue of obtaining capital for enterprises' growth by issuing corporate bonds. Special attention is given to covenants, i.e. the issue conditions protecting investors' rights and their capital employed. The study attempts to answer the questions whether covenants fully protect the interests of investors, limit or increase the agency conflict between managers, owners, and creditors, to what extent these events depend on the type and number of covenants, and how they can be monitored by issuers. The consequences of covenants application and the after-effects of their violation were preceded by a brief description of the role of debt securities in financing business entities. The authors claim that adequate covenants together with the close monitoring of financial situation of the issuer can enhance the protection of investors' rights and lessen the number of violations of issue conditions.
\end{abstract}

Słowa kluczowe: kowenanty, obligacje przedsiębiorstw, źródła finansowania, konflikt i koszty agencyjne

Keywords: covenants, corporate bonds, sources of financing, agency conflict and costs

* Doktor hab. nauk ekonomicznych, profesor Akademii Ekonomiczno-

-Humanistycznejw Warszawie • e-mail: piotr.szczepankowski@wp.pl • https://orcid.org/oooo-0001-6889-8433

** Doktor nauk ekonomicznych, adiunkt na Uniwersytecie Ekonomicznym w Poznaniu • e-mail: agata.sierpinska-sawicz@ue.poznan.pl • https://orcid.org/oooo-0001-9890-3344

\section{Wstęp}

Do głównych czynników determinujących rozwój przedsiębiorstw należy łatwość dostępu i możliwość wyboru źródeł finansowania działalności gospodarczej. Dynamiczny rozwój rynków finansowych powoduje, że jednostki gospodarcze dysponują zróżnicowaną ofertą kapitałów, a niemałą rolę w ich pozyskaniu odgrywają preferencje menedżerów i właścicieli przedsiębiorstw 
oraz skłonność inwestorów do pokrycia potrzeb finansowych podmiotów. Powoduje to, że coraz częściej zainteresowane strony koncentrują uwagę na rynku obligacji korporacyjnych.

Wykorzystywanie długu rynkowego przez przedsiębiorstwa wynika z potrzeby dywersyfikacji źródeł finansowania, ukształtowania korzystnej struktury kapitału oraz ograniczenia stopnia uzależnienia od jednego wierzyciela. Bodźcem emitowania obligacji korporacyjnych jest również podaż kredytów. Ostatni kryzys finansowy doprowadził do zaostrzenia norm ostrożnościowych i sprawił, że wiele banków ograniczyło politykę kredytowania przedsiębiorstw. Ustanowione restrykcje w dostępności do finansowania bankowego skierowały istniejący popyt na kapitał w stronę źródeł pozabankowych, dostępnych na rynku finansowym.

Stały wzrost zainteresowania rynkiem długu korporacyjnego powoduje, że emitenci obligacji poszukują mechanizmów zwiększenia popytu na nie, a inwestorzy oczekują zastosowania przez emitentów środków skutecznej ochrony pozyskanego kapitału. Coraz częściej interesy obligatariuszy są zabezpieczane kowenantami zapisywanymi w warunkach emisji długu. Zobowiązują one inwestora do określonych działań wobec emitenta wówczas, gdy wystąpią określone zdarzenia niezgodne $\mathrm{z}$ ustalonymi warunkami emisji.

Z punktu widzenia emitenta konsekwencją kowenantów jest usztywnienie prowadzonej działalności, ograniczenie swobody decyzyjnej czy możliwości dowolnego gospodarowania pozyskanymi środkami finansowymi, ale również gwarancja przeprowadzenia emisji z sukcesem oraz obniżenie kosztu długu. Dla inwestorów z kolei kowenanty zapewniają ochronę kapitału, obniżają poziom odczuwanego ryzyka wywoływanego niepożądanymi działaniami emitenta i ograniczają asymetrię informacji oraz konflikt agencyjny, jaki powstaje między zarządzającymi przedsiębiorstwem, jego właścicielami i wierzycielami.

Na podstawie kwerendy literatury oraz wyników wybranych badań przeprowadzonych $\mathrm{w}$ Polsce podjęto $\mathrm{w}$ artykule próbę oceny roli kowenantów w ochronie praw i kapitału obligatariuszy z uwzględnieniem znaczenia obligacji w finansowaniu rozwoju przedsiębiorstw. Opracowanie ma charakter teoretyczny. Systematyzuje wiedzę z zakresu omawianego zagadnienia oraz uczestniczy w dyskusji na temat ważności stosowania i przestrzegania kowenantów zawartych w warunkach emisji długu.

Z przesłanek stosowania kowenantów wynika cel pracy. Jest nim próba odnalezienia odpowiedzi na kilka pytań problemowych, a mianowicie: czy klauzule umowne są w stanie chronić interesy inwestorów i w związku z tym ułatwić emitentom pozyskanie kapitału dłużnego na rynku, czy ograniczają, a może nasilają konflikt interesów między menedżerami, właścicielami i wierzycielami przedsiębiorstw, który skutkuje wzrostem kosztu kapitału i hamuje efektywne wykorzystanie obligacji jako instrumentu finansowania programu 
rozwoju przedsiębiorstwa oraz w jakim stopniu zdarzenia te zależą od rodzaju oraz liczby kowenantów, a także sposobów monitorowania ich przestrzegania przez emitentów.

Przedstawione opinie i wnioski mogą okazać się interesujące dla emitentów obligacji, organizatorów emisji, inwestorów oraz instytucji nadzoru nad rynkiem finansowym.

\section{Rola obligacji w finansowaniu rozwoju przedsiębiorstw}

Aktywność operacyjna i inwestycyjna podmiotów gospodarczych wymaga zróżnicowanych rodzajów kapitału. Zgodnie z teorią hierarchii źródeł finansowania, w pierwszej kolejności przedsiębiorstwa korzystają z kapitału wewnętrznego, tj. zrealizowanych i zatrzymanych zysków, utworzonych rezerw oraz środków pieniężnych uwolnionych wskutek zmian wartości aktywów trwałych (amortyzacja, deinwestycje) oraz składników kapitału obrotowego netto (zapasy, należności i zobowiązania bieżące). Jeśli środki te okazują się niewystarczające do pokrycia planowanych potrzeb rozwojowych, jednostka gospodarcza sięga do źródeł zewnętrznych, najczęściej kapitałów obcych.

Poszukując odpowiednich środków finansowania rozwoju, przedsiębiorstwo uwzględnia wiele kryteriów podjęcia właściwej decyzji wyboru, jak: dostępność do danego źródła, koszt pozyskania kapitału, ryzyko finansowe, swoboda dysponowania kapitałem, stopień rozproszenia dostawców kapitału oraz miejsce jego pozyskania. W tym ostatnim przypadku kapitały zewnętrzne mogą pochodzić z sektora bankowego albo z rynku finansowego. W systemie finansowym zorientowanym na banki, obowiązującym w większości krajów europejskich, w tym w Polsce, kredyt jest podstawowym zewnętrznym źródłem finansowania działalności rozwojowej przedsiębiorstw, choć systematycznie rośnie rola długoterminowych papierów dłużnych emitowanych przez podmioty gospodarcze - obligacji (tabela 1).

Tabela 1. Wartość głównych składników zadłużenia długoterminowego przedsiębiorstw w Polsce (stan na koniec roku)

\begin{tabular}{|l|r|r|r|r|r|r|r|r|r|}
\hline Wyszczególnienie & $\mathbf{2 0 0 9}$ & $\mathbf{2 0 1 0}$ & $\mathbf{2 0 1 1}$ & $\mathbf{2 0 1 2}$ & $\mathbf{2 0 1 3}$ & $\mathbf{2 0 1 4}$ & $\mathbf{2 0 1 5}$ & $\mathbf{2 0 1 6}$ & $\mathbf{2 0 1 7}$ \\
\hline Kredyty & 108,8 & 107,9 & 116,7 & 119,2 & 119,4 & 127,6 & 137,7 & 132,3 & 142,9 \\
\hline Obligacje & 15,5 & 21,6 & 29,7 & 32,3 & 37,8 & 54,2 & 65,2 & 69,0 & 76,0 \\
\hline
\end{tabular}

Źródło: na podstawie danych GUS o bilansowych wynikach finansowych przedsiębiorstw oraz raportów NBP nt. rozwoju systemu finansowego w Polsce za lata 2009-2017.

Zgodnie $\mathrm{z}$ definicją prawną obligacja jest emitowanym w serii papierem wartościowym, w którym emitent stwierdza, że jest dłużnikiem właściciela obligacji, zwanego obligatariuszem, i zobowiązuje się wobec niego do spełnienia 
określonego świadczenia w zadanym czasie ${ }^{1}$. Obligacje emitowane przez osoby prawne prowadzące działalność gospodarczą lub podmioty upoważnione do ich emisji na podstawie odrębnych ustaw noszą nazwę korporacyjnych. Są dzielone na obligacje przedsiębiorstw i banków. Zgodnie z klasyfikacją ESA $2010^{2}$ w cyklicznych raportach NBP nt. rozwoju systemu finansowego w Polsce do obligacji przedsiębiorstw zalicza się papiery dłużne wyemitowane przez przedsiębiorstwa niefinansowe, pozostałe instytucje pośrednictwa finansowego ( $\mathrm{z}$ wyjątkiem instytucji ubezpieczeniowych i funduszy emerytalno-rentowych), pomocnicze instytucje finansowe oraz udzielające pożyczek. Dodatkowo są również uwzględnione obligacje emitowane przez podmioty sektora prywatnego, które zgodnie z ESA 2010 są zaliczane do jednostek samorządowych, np. spółki komunalne ${ }^{3}$.

Obligacje dają emitentom dostęp do średnio- i długoterminowych środków finansowych, pochodzących od większej liczby inwestorów. Dla przedsiębiorstwa oferującego walory dłużne istotne znaczenie ma możliwość otrzymania pożyczki na określonych zasadach, w tym przy autonomicznie ustalonym oprocentowaniu, które jest jednocześnie kosztem długu emitenta i stopą zwrotu inwestora. Obligacje umożliwiają zwykle zaciągnięcie pożyczki przy koszcie niższym niż w przypadku kredytu bankowego, a inwestorom dają szansę osiągnięcia wyższej stopy zwrotu niż z lokat bankowych czy obligacji skarbowych, równocześnie zapewniając im niższy poziom ryzyka niż inwestowanie w akcje 4 . Zobowiązania emitenta wynikające z wyemitowanych obligacji są egzekwowalne, a emitent odpowiada za nie całym swoim majątkiem ${ }^{5}$. Upublicznione i notowane na rynku papiery dłużne stają się częścią przejrzystego systemu obrotu instrumentami finansowymi, co ułatwia przenoszenie praw do wynikających z nich świadczeń, które mogą mieć charakter pieniężny (odsetki, zwrot wartości nominalnej obligacji) lub niepieniężny (udział w przyszłym zysku emitenta, prawo zamiany obligacji na kapitał własny lub też pierwszeństwo do objęcia emitowanych w przyszłości akcji emitenta $)^{6}$.

Przesłanki emisji obligacji przez przedsiębiorstwa można podzielić na:

- wewnętrzne, odnoszące się do motywów powstających w podmiocie gospodarczym, dzielonych następnie na: pierwotne, czyli takie, które są

1 Ustawa z 15 stycznia 2015 r. o obligacjach, Dz.U. poz. 238, ze zm., art. 4.

2 ESA (European System of Accounts) - europejski system rachunków narodowych i regionalnych w Unii Europejskiej.

${ }_{3}$ Rozwój systemu finansowego w Polsce w 2017 r., NBP, Warszawa 2018, s. 272, przyp. 365.

${ }^{4}$ P. Prewysz-Kwinto, Catalyst - rynek obligacji GPW w 2,5 roku od otwarcia, „Annales Universitatis Mariae Curie-Skłodowska, Sectio H” 2012, vol. XLVI, nr 4, s. 699.

5 S. Antkiewicz, Papiery wartościowe na rynku pieniężnym i kapitałowym, CeDeWu, Warszawa 2012, s. 44; Z. Konieczny, Obligacje przedsiębiorstw [w:] Instrumenty dłużne w gospodarce, red. I. Czechowska, CeDeWu, Warszawa 2010, s. 162-166.

${ }^{6}$ L. Lipiec-Warzecha, Ustawa o obligacjach. Komentarz, Wolters Kluwer, Warszawa 2010, s. $26,106-108$. 
brane pod uwagę w procesie podejmowania decyzji o emisji obligacji, oraz wtórne, będące konsekwencją dokonanej emisji,

- zewnętrzne, które są niezależne od emitenta, a wynikają z trendów kształtujących się w jego otoczeniu.

Opisany podział został przedstawiony w tabeli 2.

Tabela 2. Przesłanki emisji obligacji przez przedsiębiorstwa

\begin{tabular}{|c|c|c|}
\hline \multicolumn{2}{|c|}{ Przesłanki wewnętrzne } & \multirow{2}{*}{ Przesłanki zewnętrzne } \\
\hline Pierwotne & Wtórne & \\
\hline $\begin{array}{l}\text { - zwiększenie elastyczności } \\
\text { - finansowania } \\
\text { - niższy koszt pozyskania kapitału } \\
\text { - możliwość niezabezpieczenia } \\
\text { - mobowiązania } \\
\text { - dywersyość braku spłaty długu } \\
\text { - brak koniecznośćdeł kapitału wskazywania } \\
\text { szczegółowego celu przezna- } \\
\text { czenia środków pochodzących } \\
\text { z emisji }\end{array}$ & $\begin{array}{l}\text { - wzrost profesjonalizmu zarzą- } \\
\text { dzania finansami przedsiębior- } \\
\text { stwa } \\
\text { - } \text { wzrost wiarygodności emitenta } \\
\text { - promocja działalności emitenta } \\
\text { - wzrost szans na pozyskanie } \\
\text { kapitału w przyszłych okresach } \\
\text { - brak zmian w strukturze włas- } \\
\text { nościowej przedsiębiorstwa }\end{array}$ & $\begin{array}{l}\text { - dostęp do kapitału rynkowego } \\
\text { - dostęp do szerszego grona } \\
\text { inwestorów i brak limitów } \\
\text { koncentracji kapitału } \\
\text { - akceptacja przez rynek } \\
\text { większego ryzyka z uwagi na } \\
\text { większą liczbę inwestorów oraz } \\
\text { nadzór nad rynkiem } \\
\text { - niska podaż kredytów lub } \\
\text { trudności w dostępie do nich } \\
\text { - globalizacja gospodarki i ryn- } \\
\text { ków finansowych } \\
\text { - rozwój alternatywnych form } \\
\text { finansowania }\end{array}$ \\
\hline
\end{tabular}

Atrakcyjność emisji obligacji jest często porównywana do możliwości pozyskania kredytu w sektorze bankowym. Zwraca się przy tym uwagę na swobodę kształtowania zapisów dotyczących warunków emisji długu, co stwarza szanse na pozyskanie znacznie większych kwot kapitału niż w przypadku kredytu. W bankach obowiązują bowiem limity koncentracji kapitału, determinujące maksymalną wartość zaangażowania finansowego w poszczególne przedsiębiorstwa. Warto również zwrócić uwagę na fakt, że poprzez emisję obligacji łatwiej jest pozyskać środki na realizację przedsięwzięć ryzykownych, podczas gdy banki podchodzą do finansowania tego typu projektów dość ostrożnie.

Emisja obligacji pozwala na pozyskanie kapitału na dłuższy okres niż czas udostępnienia środków przez banki. Ograniczenia czasowe przy umowach kredytowych uwarunkowane są potrzebą utrzymywania przez banki odpowiedniego stopnia płynności posiadanych aktywów. Emitując obligacje, spółki mogą pozyskiwać kapitał w seriach, stosownie do etapu realizacji przedsięwzięć. W okresie trwania inwestycji emitent jest obciążony wyłącznie obsługą bieżących płatności odsetek, a kapitał zwraca w terminie określonym w warunkach emisji, na ogół po zakończeniu przedsięwzięcia.

Pozyskiwanie środków poprzez emisję obligacji dotyczy również samodzielności emitenta w ustalaniu wysokości i sposobu naliczania odsetek, co przekłada się na koszt kapitału. W przypadku emisji obligacji przedsiębiorstwo ma możliwość sterowania kosztami pozyskania kapitału w większym stopniu 
niż przy zaciąganiu kredytu bankowego ${ }^{7}$. Niemałą rolę w kształtowaniu kosztu kapitału ma również sposób zabezpieczenia długu. O ile przy kredycie zabezpieczenie długu ma charakter obligatoryjny, to przy emisji obligacji - fakultatywny. Emitent nie ma obowiązku oznaczenia i wyceny majątku zabezpieczającego emisję. Przy umowach kredytowych obowiązek taki występuje w większości przypadków i może ograniczać dostępność środków na finansowanie działalności gospodarczej.

Analizując możliwość wykorzystania przez przedsiębiorstwo rynkowego kapitału dłużnego, trudno nie dostrzec pewnych wad emisji obligacji. W pierwszej kolejności należy wskazać na ryzyko niepozyskania zaplanowanych kwot kapitału wskutek ograniczonego popytu inwestorów, co jest pochodną niedopasowania parametrów emisji do ich oczekiwań. Trudno jest bowiem ustalić takie warunki emisji, które odpowiadałyby wszystkim inwestorom, a równocześnie zapewniały przedsiębiorstwu opłacalność jej przeprowadzenia. Ponadto popyt na obligacje zależy nie tylko od czynników wewnętrznych, wynikających $\mathrm{z}$ sytuacji finansowej emitenta, ale również od zmian koniunkturalnych w jego otoczeniu.

Co do wad emisji obligacji podnoszony jest niekiedy problem wysokich kosztów transakcyjnych związanych z przygotowaniem emisji i wprowadzeniem jej na rynek. Rozstrzygnięcie tego problemu staje się wyjątkowo trudne, gdyż wysokość kosztów zależy od indywidualnych negocjacji emitenta $\mathrm{z}$ agentem emisji, warunków dotychczas realizowanych umów oraz historii i jakości współpracy obu podmiotów. Należy dodać, że część kosztów związanych z emisją obligacji ma charakter stały i jeśli rozłożą się one na większą kwotę emisji, mogą zapewnić relatywną obniżkę jednostkowego kosztu pozyskania kapitału.

Niekorzystnym zjawiskiem związanym z emisją obligacji są również ograniczone możliwości renegocjacji warunków finansowania. Oferta złożona potencjalnym inwestorom jest wiążąca. W sytuacji zmiany kondycji finansowej przedsiębiorstwa lub niekorzystnej koniunktury gospodarczej, powodującej drastyczny spadek wyników finansowych osiąganych przez emitenta, nie może on dokonać zmian w warunkach emisji. Obligatariusze mogą natomiast zażądać natychmiastowego wykupu obligacji.

Ograniczenia w pozyskiwaniu środków finansowych poprzez emisję obligacji można zatem zakwalifikować do dwóch grup. Na pierwszą składają się czynniki wewnętrzne, czyli takie, które powstają na skutek decyzji zarządu i działań przedsiębiorstwa podejmowanych $\mathrm{w}$ związku z emisją. Wśród nich wymienia się często niewystępowanie o rating, brak ustalenia zabezpieczenia powstającej wierzytelności oraz niedostateczną znajomość rynku papierów dłużnych, procedur i uwarunkowań prawnych emisji. Z kolei ograniczenia drugiego rodza-

7 A. Sierpińska-Sawicz, P. Bąk, Costs of corporate bond issue in coal mining companies, „Contemporary Economics” 2016, vol. 10, nr 2, s. 99-112. 
ju, zewnętrzne, obejmują sytuację rynkową, na którą przedsiębiorstwo nie ma wpływu, a która determinuje możliwość pozyskania kapitału w wyniku emisji obligacji. W tym wypadku wymienia się: niską płynność rynku, skomplikowaną oraz kosztowną procedurę emisji, ryzyko niewypłacalności emitentów, obrót wtórny głównie na rynku nieuregulowanym, niskie zainteresowanie inwestorów instytucjonalnych, dominację obligacji nominowanych w walucie krajowej, wzrost stóp procentowych oraz inflację.

Obserwowany w ostatnich latach wzrost zainteresowania obligacjami przedsiębiorstw w Polsce jest również efektem zmian regulacyjnych, które skoncentrowały się na poprawie transparentności i zabezpieczenia interesów inwestorów oraz liberalizacji zasad emisji i obrotu walorami dłużnymi. Ustawa z 29 czerwca 2000 r. ${ }^{8}$ złagodziła warunki emisji długu korporacyjnego. Zarzucono obowiązek wskazywania celu emisji obligacji, rozszerzono krąg podmiotów o zdolności emisyjnej i zwiększono liczbę możliwych zabezpieczeń. Wprowadzono również możliwość dokonywania oferty publicznej bez konieczności stosowania ustawy o ofercie publicznej.

Poprzez uchwalenie ustawy z 8 marca 2013 r. ${ }^{9}$ dokonano zmian mających na celu ułatwienie emitentom dostępu do rynkowego finansowania dłużnego. Zmieniono definicję oferty publicznej, która poskutkowała zwiększeniem minimalnej liczby inwestorów do 150 . Umożliwiono przeprowadzanie oferty publicznej o wartości emisji obligacji nieprzekraczającej 2,5 mln euro w ciągu dwunastu miesięcy bez przygotowania prospektu emisyjnego. Niewątpliwymi zaletami tej zmiany było obniżenie kosztów emisji i skrócenie jej czasu, brak procedury zatwierdzenia przez Komisję Nadzoru Finansowego memorandum informacyjnego, które należy jedynie opublikować, i umożliwienie prowadzenia, zatwierdzonej przez Komisję, akcji promocyjnej do nieoznaczonego inwestora. Wymagane stało się również korzystanie z usług firmy inwestycyjnej jako pośrednika procesu emisji. Zniesienie obowiązku prospektu emisyjnego stało się szansą dla mniejszych przedsiębiorstw, które pierwotnie mogły korzystać $\mathrm{z}$ oferty prywatnej, a teraz mogą pozyskać inwestorów ze zdecydowanie szerszego kręgu. Wprowadzono również możliwość prowadzenia przez emitentów ofert kaskadowych na określonych przez siebie warunkach i w wybranych terminach.

W dniu 1 lipca 2015 r. weszła w życie nowa ustawa o obligacjach ${ }^{10}$. Intencją uchwalonych zmian było doprowadzenie do sytuacji, w której emisja obligacji zacznie pełnić rolę dodatkowego, komplementarnego w stosunku do kredytów

8 Ustawa z 29 czerwca 2000 r. o zmianie ustawy o obligacjach i niektórych innych ustaw, Dz.U. nr 60, poz. 702.

9 Ustawa z 8 marca 2013 r. o zmianie ustawy o ofercie publicznej i warunkach wprowadzania instrumentów finansowych do zorganizowanego systemu obrotu oraz o spółkach publicznych oraz niektórych innych ustaw, Dz.U. poz. 433.

10 Zob. przypis 1. 
źródła pozyskania kapitału przez przedsiębiorstwa. Ustawa nadała zdolność emisyjną nowym podmiotom gospodarczym, m.in. spółkom specjalnego przeznaczenia (celowym $)^{11}$. Wprowadzono także nowe rodzaje obligacji, takie jak: wieczyste, dla których nie określa się terminu zapadalności, a wypłata odsetek następuje $\mathrm{w}$ formie renty wieczystej, oraz podporządkowane, $\mathrm{z}$ których dochodzone roszczenia, w przypadku braku spłaty obligacji na skutek upadłości lub likwidacji emitenta, są egzekwowane w kolejności ustalonej w warunkach emisji ${ }^{12}$. Ustawa wprowadziła również możliwość powoływania instytucji zgromadzenia obligatariuszy, rozumianego jako reprezentacja ogółu inwestorów uprawnionych z tytułu posiadanych obligacji danej serii i ich interesów wobec emitenta. Wprowadzono także instytucję administratora zabezpieczeń dla innych form niż hipoteka czy zastaw rejestrowy. Sprecyzowano wymogi dotyczące wyceny zastawu lub hipoteki. Dodatkowo umożliwiono dokonywanie zabezpieczeń po emisji obligacji. Poszerzono zakres informacji niezbędnych do wskazania w warunkach emisji. Na emitentów nałożono obowiązek publikowania informacji na stronie internetowej przedsiębiorstwa.

Zmiany powodujące wzrost transparentności emitentów i ochronę inwestorów nastąpiły na poziomie prawa wspólnotowego w wyniku wejścia w życie regulacji MAR (Market Abuse Regulation) dotyczących nadużyć na rynku ${ }^{13}$. Przepisy te zaczęły obowiązywać od 3 lipca 2016 r. Ujednolicają one obowiązki informacyjne emitentów instrumentów finansowych na wszystkich rynkach kapitałowych Unii Europejskiej. Wśród uchwalonych zmian należy wskazać m.in. obowiązek bezzwłocznego przekazywania przez emitentów informacji do publicznej wiadomości oraz poszerzony obowiązek informowania o transakcjach na obligacjach przez osoby mające dostęp do informacji poufnych, $\mathrm{np}$. osoby pełniące funkcje zarządcze $\mathrm{w}$ spółce emitenta oraz blisko $\mathrm{z}$ nimi związane.

Atrakcyjność obligacji jako źródła finansowania przedsiębiorstw oraz zmiany regulacyjne, których konsekwencją stała się poprawa transparentności emisji, emitentów i obrotu walorami dłużnymi, a także ochrony praw obligatariuszy, spowodowały, że wzrosło zainteresowanie kowenantami.

11 A. Bielawska, M. Pawłowski, Rynek obligacji korporacyjnych $w$ Polsce w obliczu zmian legislacyjnych. Przegląd kluczowych rozwiązań w ustawie z dn. 15 stycznia 2015 r. o obligacjach, „Kwartalnik Kolegium Ekonomiczno-Społecznego SGH. Studia i Prace” 2013, nr 3, t. 3, s. 43.

${ }_{12}$ Ibidem, s. 43-45; M. Wiśniewski, Obligacje podporzadkowane, wieczyste i przychodowe w Polsce - próba oceny ekonomicznych skutków nowelizacji ustawy o obligacjach, „Ruch Prawniczy, Ekonomiczny i Socjologiczny" 2016, nr 1, s. 185-186.

13 Rozporządzenie Parlamentu Europejskiego i Rady (UE) nr 596/2014 z 16 kwietnia 2014 r. w sprawie nadużyć na rynku oraz uchylające dyrektywę 2003/6/WE Parlamentu Europejskiego i Rady i dyrektywy Komisji 2003/124/WE, 2003/125/WE i 2004/72/WE, Dz.Urz. UE L 173 z 12 czerwca 2014 r. 


\section{Istota i rodzaje kowenantów w emisjach obligacji}

Przez kowenanty rozumie się klauzule umowne zawarte w warunkach emisji długu, które zobowiązują dłużnika do podejmowania lub zaniechania określonych działań do czasu spłaty zobowiązania. Obejmują zarówno zakazy, jak i nakazy odnoszące się do jego sytuacji finansowej, majątkowej, inwestycyjnej oraz prawnej ${ }^{14}$. Podstawowym celem stosowania kowenantów w emisjach obligacji jest nałożenie na działalność emitenta takich ograniczeń, które zmniejszą ryzyko jego niewypłacalności i stworzą obligatariuszom możliwość odzyskania zainwestowanych środków kapitałowych lub otrzymania zwiększonych świadczeń w wyniku wzrostu ponoszonego przez nich ryzyka inwestycyjnego ${ }^{15}$. Zadaniem kowenantów jest więc ochrona źródeł spłaty zobowiązań emitenta poprzez utrzymanie wybranych wskaźników finansowych na określonym poziomie oraz powstrzymanie się od działań ograniczających jego zdolność do regulowania wierzytelności. Podstawowa różnica pomiędzy kowenantami i klasycznymi zabezpieczeniami, takimi jak zastaw, hipoteka czy poręczenie, wynika z faktu, że działają one nawet wówczas, gdy dłużnik terminowo płaci zobowiązania odsetkowe, ale jego sytuacja finansowa zmienia się w taki sposób, że może to zagrozić przyszłej spłacie długu.

Oprócz funkcji zabezpieczającej interesy obligatariuszy kowenanty pełnią rolę dyscyplinującą menedżerów. W kontraktach menedżerskich często bowiem są zapisywane wskaźniki, których uzyskanie jest podstawą premiowania zarządu przedsiębiorstwa. Menedżerowie w takiej sytuacji mogą podejmować działania rozwojowe nie tyle w interesie kapitałodawców, lecz własnym. Kowenanty są w stanie hamować pokusę nadużyć w tym zakresie. Zarządzający muszą liczyć się bowiem z zapisami warunków emisji długu, które ograniczą nadmierną swobodę podejmowania decyzji z niekorzystnymi skutkami dla wierzycieli.

Kowenanty zawarte w warunkach emisji obligacji odnoszą się przede wszystkim do konieczności utrzymywania przez emitenta określonego poziomu relacji ekonomicznych stosowanych do oceny sytuacji finansowej przedsiębiorstwa. Ponadto emitent powinien powstrzymywać się od:

- zaciągania kolejnych zobowiązań,

- zbywania aktywów bądź obciążania ich zastawami i hipotekami,

- dokonywania połączeń z innymi podmiotami, podziałów spółki lub przejęć innych przedsiębiorstw,

- zagospodarowania zysku netto powyżej poziomu przyjętego w kowenantach,

- zaprzestania określonej działalności gospodarczej lub rozpoczynania jej w nowych obszarach.

14 B. Brycz, M. Pauka, Ograniczenia transferów do właścicieli w kowenantach obligacji notowanych na rynku Catalyst, „Finanse, Rynki Finansowe, Ubezpieczenia” 2017, nr 2 (86), s. 173.

${ }_{15}$ N. Śmieja, M. Pauka, Zastosowanie kowenantów w warunkach emisji obligacji - badania empiryczne wśród emitentów z branży deweloperskiej w Polsce, „Zeszyty Naukowe Uniwersytetu Szczecińskiego. Finanse, Rynki Finansowe, Ubezpieczenia” 2013, nr 62, s. 400. 
Tabela 3. Podział kowenantów

\begin{tabular}{|c|c|c|}
\hline Grupa & Rodzaj & Przykładowe klauzule \\
\hline \multirow[t]{4}{*}{ Finansowe } & $\begin{array}{l}\text { dotyczące transferu } \\
\text { środków pieniężnych }\end{array}$ & $\begin{array}{l}\text { - } \text { ograniczające lub zakazujące wypłaty dywidend } \\
\text { - ograniczające lub zakazujące skupowania i umarzania włas- } \\
\text { nych akcji } \\
\text { - ograniczające lub zakazujące stosowanie cen transferowych } \\
\text { - zakazujące ponoszenia nieuzasadnionych kosztów }\end{array}$ \\
\hline & - dotyczące aktywów & $\begin{array}{l}\text { - zakazujące sprzedaży kluczowych aktywów } \\
\text { - nakazujące ubezpieczenie wybranych aktywów } \\
\text { - zakazujące łączenia się z innymi podmiotami } \\
\text { - ograniczające procesy restrukturyzacji } \\
\text { - zakazujące obciążania aktywów } \\
\text { - zakazujące udzielania pożyczek innym podmiotom }\end{array}$ \\
\hline & $\begin{array}{l}\text { - dotyczące źródeł } \\
\text { finansowania }\end{array}$ & $\begin{array}{l}\text { - nakazujące utrzymanie określonego poziomu zadłużenia } \\
\text { - nakazujące utrzymanie zdolności do obsługi długu } \\
\text { - ograniczające lub zakazujące emisji nowego długu } \\
\text { - ograniczające lub zakazujące emisji akcji }\end{array}$ \\
\hline & - dotyczące inwestycji & $\begin{array}{l}\text { - zakazujące podejmowania inwestycji innych niż te finansowa- } \\
\text { ne emisją obligacji } \\
\text { - zakazujące nabywania aktywów od podmiotów powiązanych } \\
\text { - nakazujące podejmowanie opłacalnych okazji inwestycyjnych }\end{array}$ \\
\hline Niefinansowe & $\begin{array}{l}\text { - obligujące emitenta } \\
\text { do podejmowania } \\
\text { określonych działań }\end{array}$ & $\begin{array}{l}\text { - udostępnianie w wyznaczonym terminie istotnych informacji } \\
\text { finansowych i pozafinansowych, w tym także działań plano- } \\
\text { wanych do realizacji } \\
\text { - dostarczanie opisu istotnych czynników ryzyka i innych } \\
\text { zdarzeń ważnych dla emitenta } \\
\text { - wprowadzenie wyemitowanych obligacji do obrotu na rynku } \\
\text { regulowanym }\end{array}$ \\
\hline
\end{tabular}

Dodatkowo w kowenantach mogą znaleźć się zapisy, które zobowiązują emitenta do ustanowienia zabezpieczeń obligacji oraz spełniania zasady cross-default, czyli prawa żądania natychmiastowego wykupu obligacji, w przypad$\mathrm{ku}$ gdy emitent naruszy inne zobowiązania finansowe (np. z tytułu innej serii obligacji). W zasadzie lista nakazów i zakazów mogących wystąpić w postaci kowenantów jest nieograniczona.

Kowenanty najogólniej dzieli się na dwie grupy: niefinansowe oraz finansowe, zwane też księgowymi (accounting-based covenants). Pierwsze z nich mają formę opisową. Są klauzulami o charakterze jakościowym. Zobowiązują kadrę menedżerską do stosowania określonych zasad, podjęcia pewnych działań czy wywiązania się z określonych obowiązków.

Zdecydowana większość wykorzystywanych w praktyce kowenantów ma charakter finansowy. Są wprowadzane do umów obligacyjnych w formie maksymalnych albo minimalnych poziomów wybranych wielkości finansowych (klauzule ilościowe), ale mogą też mieć formę opisową (klauzule jakościowe). Odwołują się one bądź do wyników finansowych emitenta (kowenanty wynikowe), bądź do decyzji z zakresu gospodarowania zasobami majątkowo-kapitałowymi (kowenanty kapitałowe) ${ }^{16}$. Kowenanty finansowe dzielone są jeszcze

16 H.B. Christensen, V.V. Nikolaev, Capital versus performance covenants in debt contracts, The University of Chicago, Booth School of Business Research Paper nr 11-06, 2011, s. 1-58. 
na: do utrzymania (maintenance covenants) oraz zdarzeniowe (incurrence covenants). Pierwsze należy stosować cały czas, niezależnie od działań podejmowanych przez emitenta, drugie zaś nie pozwalają przeprowadzać konkretnych działań, jeśli miałoby to doprowadzić do przekroczenia progowych wartości określonych wskaźników finansowych ${ }^{17}$.

Szczegółowy podział kowenantów, z wyodrębnieniem ich rodzajów w danej grupie oraz wykazem przykładowych rozwiązań, został przedstawiony w tabeli 3.

Dużą popularnością cieszą się kowenanty dotyczące źródeł finansowania emitenta, które łatwo można kontrolować, wykorzystując w tym celu wybrane wskaźniki finansowe, dotyczące:

- poziomu zadłużenia emitenta, mierzonego relacjami:

- zobowiązań ogółem do aktywów ogółem,

- zadłużenia finansowego ${ }^{18}$ do kapitału własnego,

- zadłużenia ogółem do kapitału własnego,

- długu netto ${ }^{19}$ do kapitału własnego,

- zdolności emitenta do obsługi długu, wyrażonej takimi relacjami, jak:

- dług netto do EBITDA ${ }^{20}$,

- suma zysku netto i amortyzacji do rocznej kwoty obsługi długu (odsetki),

- zadłużenie finansowe do EBITDA,

- EBITDA do odsetek.

Interesującym przypadkiem kowenantów dotyczących źródeł finansowania są zakazy lub ograniczenia emisji nowego długu. Tym sposobem obligatariusz chce zapewnić sobie, że z wyjątkiem zadłużenia uruchamianego w ramach programu emisji, emitent nie zwiększy ryzyka niewypłacalności poprzez pozyskanie innego finansowania niż zadłużenie dozwolone ${ }^{21}$. Uruchomienie dodatkowego zadłużenia niż określone w warunkach emisji wiąże się także z emisją długu na zasadzie pari pass (równego traktowania wierzycieli). Ograniczenia te mają słu-

17 A. Achleitner, R. Braun, B. Hinterramskogler, F. Tappeiner, Structure and determinants of financial covenats in leveraged buyouts, „Review of Finance” 2012, vol. 16, nr 3, s. 647-684; B. Brycz, M. Pauka, N. Śmieja, Znaczenie kowenantów na rynku obligacji korporacyjnych $w$ teorii $i$ w badaniach empirycznych - przeglad literatury, „Zeszyty Naukowe Uniwersytetu Szczecińskiego. Finanse, Rynki Finansowe, Ubezpieczenia” 2015, nr 74(1), s. 23-34.

${ }_{18}$ Przez zadłużenie finansowe rozumie się sumę długów generujących koszty finansowe, do których należą odsetki, marże, prowizje, dyskonta oraz różnice kursowe przy długach zaciągniętych w walutach obcych.

19 Dług netto to kwota zadłużenia generującego koszty pomniejszona o posiadane przez przedsiębiorstwo środki pieniężne i ich ekwiwalenty.

${ }^{20}$ EBITDA to zysk z działalności operacyjnej powiększony o wartość odpisów amortyzacyjnych.

${ }^{21}$ M. Sierpińska, A. Sierpińska-Sawicz, R. Węgrzyn, Controlling finansowy w przedsiębiorstwie, Wydawnictwo Naukowe PWN, Warszawa 2019, s. 238-239. 
żyć zwiększeniu prawdopodobieństwa odzyskania kapitału przez obligatariuszy oraz zmniejszeniu ryzyka upadłości przedsiębiorstwa ${ }^{22}$.

Często w warunkach emisji obligacji pojawiają się kowenanty finansowe ograniczające ryzyko transferu przepływów pieniężnych do właścicieli przedsiębiorstwa, co ma łagodzić konflikt interesów między nimi i obligatariuszami. Przyjmując kryterium wpływu na transfery finansowe do właścicieli, można wyróżnić kowenanty ${ }^{23}$ :

- bezpośrednio odnoszące się do tych transferów (zakazujące, ograniczające czy je warunkujące),

- pośrednio wpływające na ograniczenie takich transferów (związane ze źródłami ich finansowania).

Transfery do właścicieli mogą przybrać różną formę, często ukrytą. Poza wypłatą dywidend czy skupem akcji własnych i ich umarzaniem, w literaturze wskazuje się również na wynagrodzenie dla właścicieli oraz transakcje z właścicielami na warunkach nierynkowych. Identyfikacja, a następnie zablokowanie takich działań są bardzo trudne ${ }^{24}$.

Najprostszą formą transferu środków pieniężnych do właścicieli są dywidendy. W warunkach emisji obligacji zakłada się, że przedsiębiorstwo może wytransferować tylko pewien bezpieczny poziom zysku netto (np. nie więcej niż $20 \%$ ). W literaturze podkreśla się jednak, że zapisy te są nieskuteczne i wymienia się przyczyny tego zjawiska. Przedstawiono je poniżej ${ }^{25}$.

- Istnieje wiele innych możliwości transferu kapitału do właścicieli, często $\mathrm{w}$ formie niepieniężnej.

- Bodźce inwestycyjne wciąż pozostają nie do końca właściwe, a nawet najlepsza strategia inwestycyjna z punktu widzenia właścicieli nie jest najlepszą według kryterium podnoszenia wartości przedsiębiorstwa. Właściciele preferują bardziej inwestycje w aktywa ryzykowne, przynoszące wysoki zwrot w krótkim czasie niż przedsięwzięcia bezpieczne, dające wzrost wartości kapitału w dłuższym okresie.

- Jeśli obowiązują ograniczenia w wypłacie dywidend, mogą one w pewnych niekorzystnych sytuacjach zmusić przedsiębiorstwa do inwestowania nadwyżki środków pieniężnych w aktywa nieefektywne ekonomicznie, tj. o ujemnym wskaźniku wartości obecnej netto (NPV).

22 E. Królikowska, A. Sierpińska-Sawicz, Rodzaje kowenantów zawartych w programach emisji obligacji w spółkach węglowych, „Gospodarka Surowcami Mineralnymi” 2016, t. 32, nr 2, s. 145.

${ }^{23}$ A. Kalay, Dividend constraints in bond covenants, "Journal of Financial Economics" 1982, nr 10, s. 211-233.

${ }_{24}$ B. Brycz, M. Pauka, Ograniczenia transferów, op. cit., s. 174.

${ }_{25}$ M. Pauka, B. Brycz, Kowenanty dywidendowe na rynku obligacji Catalyst, „Finanse, Rynki Finansowe, Ubezpieczenia” 2016, vol. 82, nr 4, s. 241. 
- Ograniczenia wypłaty dywidend są pomocne jedynie wtedy, gdy jednostka gospodarcza posiada bieżące nadwyżki środków pieniężnych, które mogłaby przeznaczyć na transfery do właścicieli. W sytuacji braku wolnych środków, a także okazji inwestycyjnych, kowenanty dywidendowe nie mają natomiast większego znaczenia.

Kowenanty ograniczające transfer zysku do właścicieli są zwykle stosowane w państwach, gdzie restrykcyjność polityki dywidend jest mniejsza. Podkreśla się dodatkowo, że przedsiębiorstwa o dużym poziomie zadłużenia częściej zawierają $\mathrm{w}$ warunkach emisji kowenanty dywidendowe oraz ograniczające zaciąganie dodatkowego długu ${ }^{26}$. Z kolei podmioty o dużych możliwościach inwestycyjnych dążą do zachowania swobody w zakresie wypłat dywidend i emisji długu w przyszłości, dlatego rzadziej stosują tego rodzaju klauzule ${ }^{27}$.

Częstym warunkiem zawartym w emisjach obligacji jest zastrzeżenie, że emitent nie będzie podejmował innej aktywności niż ta związana $z$ oferowaniem, emitowaniem, obsługą oraz wykupem, refinansowaniem lub umarzaniem obligacji. Powszechną praktyką jest ograniczenie lub zakaz emisji udziałów bądź akcji, które mogą znaleźć się w posiadaniu podmiotu niebędącego np. poręczycielem programu emisji. Ważne są również kowenanty związane z ochroną aktywów. Dotyczą m.in. obowiązku ich ubezpieczenia, zakazu sprzedaży, konsolidacji z zasobami innymi podmiotów czy restrukturyzacji. Często zobowiązują one także emitenta do nieobciążania obecnego lub przyszłego majątku na rzecz innych podmiotów, poza zabezpieczeniami ustanowionymi na spłatę zobowiązań z tytułu emisji obligacji lub realizację postanowień warunków emisji.

\section{Konsekwencje stosowania kowenantów i problematyka ich naruszania}

Duża różnorodność kowenantów powoduje, że emitenci powinni dążyć do odnalezienia racjonalnego ich zbioru, właściwej struktury, w wyniku czego koszty i korzyści związane z ich zastosowania będą się co najmniej równoważyć, a w praktyce powinna wystąpić przewaga korzyści nad bezpośrednimi i pośrednimi kosztami ich wdrożenia. Problematyka ta stała się podstawą sformułowania hipotezy kosztownych kontraktów (costly contracting hypothesis) ${ }^{28}$, ściśle powiązanej z zagadnieniem kosztów transakcyjnych oraz teorią konfliktu i kosztów

${ }^{26}$ N. Reisel, On the value of restrictive covenants: Empirical investigation of public bond issues, „Journal of Corporate Finance” 2014, nr 27, s. 251-268.

${ }_{27}$ M. Pauka, B. Brycz, Kowenanty dywidendowe, op. cit., s. 241.

28 W. Smith Jr., J.B. Warner, On financial contracting. An analysis of bond covenants, „Journal of Financial Economics” 1979, nr 7, s. 117-161. 
agencyjnych ${ }^{29}$, rozwiniętej o aspekt długu ${ }^{30}$. Przyjęto w niej, że kowenanty, mając za podstawowe zadanie ochronę obligatariuszy, a także ograniczenie odczuwanego przez nich ryzyka inwestycyjnego, powinny niwelować źródła konfliktu interesu między wierzycielami, właścicielami oraz menedżerami spółki, co doprowadzi do wzrostu wartości przedsiębiorstwa i ułatwi zaspokojenie roszczeń kapitałodawców ${ }^{31}$. Łagodzenie kowenantami konfliktu interesów jest głównym zagadnieniem poruszanym przy omawianiu konsekwencji ich stosowania ${ }^{32}$.

Podłożem tego konfliktu jest odmienne postrzeganie celów i kierunków przyszłego rozwoju przedsiębiorstwa, inna ocena ryzyka działalności gospodarczej, jak również odmienne prawa oraz możliwości dostępu do przepływów pieniężnych generowanych przez przedsiębiorstwo. Wspomniano, że właściciele mogą ukierunkowywać prowadzoną przez zarząd politykę wzrostu i rozwoju podmiotu na podejmowanie aktywności zbyt ryzykownych, o niskiej efektywności ekonomicznej, co mogłoby obniżyć wartość przedsiębiorstwa i jego zasobów, a także wysokość przyszłych transferów środków finansowych do posiadaczy obligacji ${ }^{33}$. Ponadto wybór mniej efektywnych inwestycji finansowanych długiem spowoduje narastanie efektu asymetrii informacji ${ }^{34}$, a wynikające $z$ tego tytułu dodatkowe ryzyko obciąży w większym stopniu obligatariuszy.

Warto w tym miejscu zauważyć, że dług emitowany przez przedsiębiorstwo zawiera w sobie składnik finansowy (kapitałowy) i strukturalny (majątkowy). Pierwszy podlega ryzyku finansowemu, gdyż wartość długu i jego koszt zmieniają się zgodnie ze zmianami stóp procentowych na rynku. Drugi natomiast podlega ryzyku biznesowemu, szacowanemu na podstawie zmienności wartości aktywów. Przepływy pieniężne dla obligatariuszy zwykle nie zależą od tego drugiego komponentu, choć każda zmiana ryzyka biznesowego pociąga za sobą odpowiednią zmianę wartości aktywów spółki, z czego więcej utraconych korzyści przypada wierzycielom przedsiębiorstwa niż jego właścicielom.

W literaturze podkreśla się równie często, że stosowanie kowenantów w emisjach obligacji przez przedsiębiorstwa może przyczyniać się do obniżenia kosztu

${ }^{29}$ M.C. Jensen, W.H. Meckling, Theory of the firm: Managerial behavior, agency cost, and capital structure, „Journal of Financial Economics” 1976, nr 3(4), s. 305-360.

30 S.C. Myers, Determinants of corporate borrowing, "Journal of Financial Economics" 1977, nr 5, s. 147-175.

${ }^{31}$ W. Smith Jr., J.B. Warner, On financial, op. cit.; S.C. Myers, Determinants, op. cit.

32 R. Nash, J. Netter, A. Poulsen, Determinants of contractual relations between shareholders and bondholders: Investment opportunities and restrictive covenants, „Journal of Corporate Finance" 2003, nr 9.

33 B. Brycz, M. Pauka, N. Śmieja, Zastosowanie kowenantów, op. cit., s. 25.

${ }^{34}$ W ekonomii wyróżnia się trzy skutki asymetrii informacji: negatywną selekcję (błędna ocena efektywności przedsięwzięcia), pokusę nadużycia (zatajanie informacji o rzeczywistym ryzyku przedsięwzięcia) i koszty monitoringu (konieczność weryfikacji stopnia efektywności przedsięwzięcia). 
pozyskania przez nie kapitału obcego wskutek redukcji ryzyka odczuwanego przez obligatariuszy. Największy wpływ na zmniejszenie kosztu długu emitenta mają kowenanty dotyczące jego sytuacji finansowej. Obniżają ją koszt pozyskania kapitału, ale tylko w przypadku emisji przez duże podmioty, których wielkość opisana jest poziomem przychodów ze sprzedaży ${ }^{35}$. Wydaje się jednak, że w kontekście analizy skutków stosowania kowenantów lepszą miarą wielkości przedsiębiorstwa byłaby wartość jego aktywów, gdyż to one stanowią zabezpieczenie ryzyka niewypłacalności emitenta.

Należy jednak stwierdzić, że jeśli stosowanie kowenantów jest realizowane głównie z motywu ograniczenia konfliktu interesów, to paradoksalnie może skutkować wzrostem całkowitego kosztu długu przedsiębiorstwa, ze względu na wzrost pośrednich kosztów finansowania, m.in. agencyjnych (pośrednictwa), wdrożenia emisji (negocjacji jej warunków), informacyjnych oraz nadzoru nad emitentem.

Z punktu widzenia emitenta impuls kosztowy kowenantów przebiega jeszcze kilkoma innymi ścieżkami, które jeśli nie wpływają bezpośrednio lub pośrednio na koszt długu, to mogą zmieniać koszt kapitału własnego przedsiębiorstwa. Po pierwsze, kowenanty zmniejszają swobodę działania oraz ograniczają zdolność podmiotu do szybkiego reagowania na pojawiające się przyszłe możliwości wzrostu i rozwoju, które zapewniłyby wzrost jego wartości. Zmniejszają one również swobodę wyboru źródeł finansowania, zwiększając w ten sposób prawdopodobieństwo, że przedsiębiorstwo zacznie odczuwać niewystarczającą ilość środków finansowych pozwalających na realizację wszystkich dostępnych i efektywnych projektów inwestycyjnych lub pokrycie kapitałem obrotowym netto potrzeb płynnościowych. Po drugie, więcej kowenantów zastosowanych przy emisji obligacji zwiększa prawdopodobieństwo ich niedotrzymania, co skutkować może kosztownymi renegocjacjami warunków umowy z obligatariuszami. Naruszenia kowenantów mogą również powodować niedotrzymywanie warunków innych umów emitenta zawartych z podmiotami zainteresowanymi funkcjonowaniem przedsiębiorstwa, takimi jak: dostawcy, pracownicy i pozostali wierzyciele ${ }^{36}$. Po trzecie w końcu, więcej kowenantów w emisjach obligacji zwiększa koszty przestrzegania warunków emisji w wyniku częstszych audytów oraz wypełniania przez emitenta obowiązków informacyjnych.

Z punktu widzenia obligatariuszy kowenanty generują jeszcze inne dodatkowe koszty, które w konsekwencji zwiększają wymaganą przez inwestorów stopę zwrotu z kapitału. Po pierwsze, nabywcy obligacji muszą podejmować działania monitorujące działalność emitenta w celu systematycznego gromadzenia i prze-

${ }^{35}$ L. Moir, S. Sudarsanam, Determinants of financial covenants and pricing of debt in private debt contracts: the UK evidence, „Accounting and Business Research” 2007, vol. 37, nr 2, s. 151-166.

${ }^{36}$ W. Smith Jr., J.B. Warner, On financial, op. cit. 
twarzania informacji oraz oceny spełniania przez niego warunków emisji. Koszty monitorowania działalności emitenta ponoszone przez inwestorów są stosunkowo wysokie. Wynika to z braku koordynacji zbierania i przetwarzania przez nich informacji, rozproszonej własności obligacji oraz faktu, że tożsamość poszczególnych inwestorów zmienia się stale wskutek wtórnego obrotu walorami na rynku kapitałowym. Po drugie, zbyt duża liczba zastosowanych kowenantów może sugerować podwyższone ryzyko niewypłacalności emitenta, niespełnienie przez niego warunków emisji i w konsekwencji jest zapowiedzią poniesienia strat przez inwestorów. Ponadto wskaźniki windykacji obligacji mogą okazać się niższe niż w przypadku wierzytelności bankowych, a koszty administracyjne i sądowe wyższe. Po trzecie, zbyt restrykcyjne kowenanty mogą uniemożliwiać zarządzającym przedsiębiorstwem podejmowanie przedsięwzięć generujących dochody pozwalające spłacać pożyczkę zaciągniętą na rynku w wyznaczonym terminie wymagalności. W konsekwencji obligatariusze, godząc się na liczne kowenanty, mogą nieumyślnie przyczyniać się do obniżenia własnych korzyści. Po czwarte, kowenanty generują dodatkowe ryzyko wcześniejszego wykupu obligacji, co również oddziałuje na wzrost oczekiwanej przez inwestorów stopy zwrotu poprzez powstanie kosztu utraconych korzyści, szczególnie gdy alternatywne możliwości alokacji kapitału, zapewniające podobny zwrot w założonym horyzoncie inwestycyjnym, są trudne do znalezienia na rynku.

Przedstawione konsekwencje sugerują dwa potencjalne rozwiązania. Pierwszym z nich może być stworzenie standardu kowenantów dla obligacji przedsiębiorstw jako pewnego rodzaju minimum informacyjnego zapewniającego transparentność emitentów ${ }^{37}$. Drugim zaś wdrożenie sprawdzonych na rynku kapitałowym mechanizmów monitorowania sytuacji ekonomicznej kapitałobiorców, które dadzą odpowiednią jakość wyników oceny, uzyskanych przy niższych nakładach. Odpowiednim rozwiązaniem mogłoby okazać się rozszerzenie mechanizmu ładu korporacyjnego i dobrych praktyk na potrzeby łagodzenia asymetrii informacji oraz zagrożeń wynikających z emisji obligacji. Ład korporacyjny ogranicza bowiem chęć uchylania się menedżerów od obowiązków informacyjnych oraz podejmowania działań niezgodnych ze strategią rozwoju przedsiębiorstwa, przynoszących im prywatne korzyści z pominięciem interesu zarówno właścicieli, jak i wierzycieli ${ }^{38}$. Pomaga również monitorować zmiany wartości aktywów stanowiących zabezpieczenie pokrycia długu, zapewnia zachowanie przez przedsiębiorstwo niezbędnej płynności finansowej i dostarcza wysokiej jakości informacji pozwalającej śledzić dotrzymywanie warunków umów zawartych ze wszystkimi interesariuszami. W rzeczywistości ład korpo-

37 P. Niedziółka, Zastosowanie kowenantów finansowych w bankowości korporacyjnej, „Zeszyty Naukowe Uniwersytetu Ekonomicznego w Katowicach” 2014, nr 10(934), s. 144.

38 A. Shleifer, R. Vishny, A survey of corporate governance, „Journal of Finance" 1997, vol. 52, s. 737-783. 
racyjny może pomóc w załagodzeniu konfliktu między wierzycielami i właścicielami przedsiębiorstwa, szczególnie wtedy, gdy jednostka staje się niewypłacalna lub znajduje się blisko progu niewypłacalności. Kiedy emitent znajduje się w trudnej sytuacji finansowej, zarządzający przedsiębiorstwem, dążąc do zachowania własnej pozycji zawodowej, staje się mniej skłonny do podejmowania działań, które faworyzują właścicieli kosztem wierzycieli. W związku z tym ład korporacyjny sprzyjać będzie obniżce kosztów agencyjnych, szczególnie u tych emitentów obligacji, którzy stosują mniejszą i właściwie dobraną ich liczbę.

W przeciwieństwie do wymienionych korzyści należy pamiętać, że mechanizm ładu korporacyjnego został stworzony głównie w celu ochrony interesu właścicieli, a nie wierzycieli. W związku z tym wskazane jest utrzymanie równolegle prowadzonego ciągłego monitoringu kowenantów, w szczególności finansowych, oraz taki zakres okresowej oceny wyników emitenta, który neutralizowałby asymetrię informacyjną. Obligatariusze mogą przykładowo delegować uprawnienia do oceny sytuacji emitenta na bank kredytujący jego działalnośćc ${ }^{39}$. Kredytodawcy są bowiem lepiej poinformowani i bardziej skuteczni w monitorowaniu sytuacji finansowej dłużników. Banki wymagają zwyczajowo spełniania surowych norm ostrożnościowych, co zwiększa ich rolę jako podmiotu głębiej analizującego sytuację dłużnika. Posiadacze obligacji powinni zatem w większym zakresie polegać na bezpośrednim monitorowaniu emitentów przez banki, a nie na mechanizmach audytu wewnętrznego w przedsiębiorstwach. Ponadto banki, z racji ich związków z kredytobiorcami, poprzez udzielanie kredytów, zarządzanie gotówką lub działalność doradczą, mają dostęp do niepublicznych informacji, a tym samym są mniej narażone na negatywne zachowania dłużnika, powodujące zagrożenie jego przyszłej wypłacalności ${ }^{40}$.

Odnosząc się z kolei do problematyki niedotrzymywania kowenantów, należy zauważyć, że przyczyny tego zjawiska są mocno zróżnicowane i powstają już na etapie przygotowania oraz $w$ trakcie prowadzenia emisji obligacji. Na etapie przygotowania problem dotyczy wadliwej konstrukcji warunków emisji czy też niewłaściwego momentu jej wykonania. W przypadku wadliwej konstrukcji chodzi przede wszystkim o podstawowe parametry obligacji, takie jak: ich wartość nominalna, poziom i formuła oprocentowania, częstotliwość płatności odsetek, a także pierwotny termin wykupu. Częstymi błędami emitentów jest niedostosowanie terminów płatności odsetek do realizowanych przepływów pieniężnych lub między wpływami generowanymi przez realizowane przedsięwzięcia finansowane emisją obligacji i terminem wykupu czy płatnością kuponu

39 C. Park, Monitoring and structure of debt contracts, „Journal of Finance" 2000, vol. 55, s. 2157-2195; A. Beatty, S. Liao, J. Weber, Evidence on the determinants and economic consequences of delegated monitoring, "Journal of Accounting and Economics" 2012, vol. 53, s. $555-576$.

40 D. Diamond, Financial intermediation and delegated monitoring, „Review of Economic Studies" 1984, vol. 51, s. 393-414. 
odsetkowego ${ }^{41}$. Zdarzenia te w istotny sposób wpływają na materializację ryzyka związanego z naruszeniem postanowień programu emisji oraz niewywiązaniem się z kowenantów. Konieczne jest zatem zwrócenie uwagi na ryzyko niedotrzymania kowenantów już w momencie opracowywania warunków emisji obligacji oraz by gwarantowały one bezpieczeństwo obligatariuszy, a równocześnie nie ograniczały rozwoju emitenta. Rozwiązaniem tych problemów może okazać się wspomniana konieczność standaryzacji kowenantów.

Naruszenie kowenantów określonych w warunkach emisji obligacji sprowadza się najczęściej do ${ }^{42}$ :

- niedotrzymania poziomu wskaźników finansowych,

- przekroczenia terminów płatności odsetek lub zaniechania ich spłat w wymagalnym terminie,

- wypłaty dywidend ponad dopuszczalny poziom,

- zmiany profilu działalności emitenta, połączeń przedsiębiorstw, sprzedaży majątku i reorganizacji podmiotu gospodarczego,

- udzielania pożyczek spółkom spoza grupy kapitałowej,

- zaniechania wykupu obligacji w określonym terminie wymagalności w wyniku utraty płynności finansowej lub niewypłacalności emitenta,

- ustania zabezpieczeń programu emisji.

Skutki naruszenia kowenantów są precyzowane w warunkach emisji obligacji i muszą dawać obligatariuszom możliwość reakcji na zagrożenie niewypłacalności dłużnika. Sprowadzają się do żądania większych odsetek bądź dodatkowych premii, wprowadzenia dodatkowych zabezpieczeń długu, wcześniejszego wykupu obligacji bądź konwersji obligacji na inne papiery wartościowe emitenta lub zależnych od niego podmiotów z grupy kapitałowej. Najczęściej jednak naruszenie kowenantów prowadzi do zwiększenia kosztów finansowania długu poprzez wzrost oprocentowania. W ten sposób obligatariusze otrzymują dodatkową premię za ryzyko powstałe w wyniku naruszenia kowenantów.

Obligatariusze dowiadują się zazwyczaj o niedotrzymaniu kowenantów, gdy $\mathrm{w}$ warunkach emisji zastrzeżony został obowiązek bieżącego informowania inwestorów o zaistniałej sytuacji. Warunek taki jest zwyczajowo dyktowany przez inwestorów instytucjonalnych. Jednak żądanie przez inwestorów natychmiastowego wykupu obligacji wymaga często zgody zgromadzenia obligatariuszy, na którym może dojść do ugody w zamian za dodatkowe odsetki.

Obligatariusze nie zawsze jednak dowiadują się o złamaniu kowenantów. Zdarza się, że w warunkach emisji nie zobowiązano emitenta do poinformo-

${ }^{41}$ W. Gradoń, Emisja obligacji korporacyjnych a ryzyko uczestników rynku, „Zeszyty Naukowe Uniwersytetu Ekonomicznego w Katowicach. Studia Ekonomiczne” 2014, nr 171, s. 106-107.

${ }^{42}$ E. Królikowska, A. Sierpińska-Sawicz, Rodzaje kowenantów, op. cit., s. 147. 
wania inwestorów o takim naruszeniu. Emitent może też wykazywać poprawną sytuację w obszarze kowenantów, używając do ustalenia wartości wskaźników kowenantowych odmiennych formuł ich obliczania niż powszechnie znane. Biorąc pod uwagę takie ryzyko, w warunkach emisji obligacji formuły te powinny być ściśle doprecyzowane i umożliwiać wyliczenie wskaźników przez inwestorów na podstawie danych ze sprawozdań finansowych. Jeśli emisje są notowane na rynku długu, inwestorzy nie mają problemu $\mathrm{z}$ dostępem do informacji, a emitenci dbają o wizerunek spółki na rynku. Zdecydowanie trudniej jest natomiast wyegzekwować pełną informację od emitentów w warunkach emisji prywatnych. Inwestor powinien też znać terminy, w których może żądać dodatkowych odsetek lub przedterminowego wykupu obligacji.

Poza kwestią konsekwencji stosowania kowenantów i ich naruszania w literaturze wykazywane są również przesłanki różnic w liczbie oraz rodzaju kowenantów zawartych w publicznych i prywatnych emisjach obligacji przedsiębiorstw. Zaobserwowano, że w prywatnych ofertach emisji obligacji kowenanty są zwykle bardziej rygorystyczne i liczniejsze niż w ofertach publicznych ${ }^{43}$. Wykazano, że różnica ta wynika głównie z odmiennego stopnia koncentracji wierzycieli. W przypadku emisji prywatnej liczba wierzycieli jest ograniczona. Są nimi głównie banki oraz fundusze inwestycyjne, które angażując kapitały swoich klientów, dążą przez kowenanty do zapewnienia skutecznego instrumentu zabezpieczającego prowadzoną inwestycję finansową. Natomiast w przypadku emisji publicznej liczba obligatariuszy jest znacznie wyższa i składa się głównie z inwestorów nieinstytucjonalnych, co może powodować większe trudności w zawarciu przez nich wspólnego porozumienia w przypadku naruszenia kowenantów przez emitenta. Powoduje to, że emitent w warunkach publicznej emisji obligacji podaje takie rodzaje i liczbę kowenantów, których spełnianie może być latwo skontrolowane przez rozproszonego inwestora i które mogą być równie łatwo utrzymane przez dłużnika. Wypływa z tego wniosek, że efektywność tego instrumentu chroniącego interesy nabywców obligacji, rozumiana jako bilans korzyści i kosztów, może być mniejsza w przypadku publicznej emisji papierów dłużnych przez przedsiębiorstwa.

\section{Problematyka kowenantów w emisjach obligacji przedsiębiorstw w Polsce w świetle wyników wybranych badań}

Badania dotyczące kowenantów w warunkach emisji obligacji przedsiębiorstw prowadzone są na świecie od połowy lat 70 . XX wieku. W Polsce są jeszcze nieliczne. Pierwsze z nich opublikowano w 2013 r. Przedstawiono w nich wyniki analizy emisji obligacji spółek z sektora usług finansowych dostępnych na rynku

${ }^{43}$ F. Bazzana, E. Broccardo, The role of covenants in public and private debt, 2009, https:// ssrn.com/ abstract=1496352 [dostęp: 16 marca 2019 r.]. 
Catalyst ${ }^{44}$. Celem badania była ocena jakości stosowanych kowenantów oraz identyfikacja czynników, od których zależy ich liczba. Wykazano, że główną determinantą liczby kowenantów jest termin do wykupu obligacji - im dłuższy, tym większa liczba restrykcyjnych uwarunkowań emisji długu. Nie zaobserwowano natomiast wpływu oceny ryzyka, zastosowanej stopy oprocentowania obligacji oraz stopnia uplasowania emisji na rynku na liczbę i charakter użytych kowenantów, co może być skutkiem ich stosowania także przez tych emitentów, którzy nie są zagrożeni ryzykiem niewypłacalności i złamaniem warunków umowy z obligatariuszami. Może to również sugerować, że nabywcy obligacji w Polsce nie tyle zwracają uwagę na liczbę i rodzaj kowenantów przy podejmowaniu decyzji sfinansowania potrzeb konkretnego emitenta, ile na oferowane im korzyści z tytułu zaangażowania kapitału oraz szacunkowe prawdopodobieństwo ich otrzymania, jak i na cele przeznaczenia środków z tego źródła finansowania.

Opublikowano również wyniki badania kowenantów zastosowanych w emisjach obligacji na rynku Catalyst przez spółki branży deweloperskiej ${ }^{45}$. Celem analizy była weryfikacja hipotezy, że liczba kowenantów zależy od parametrów emisji, określających ryzyko działalności emitenta, zabezpieczenia emisji oraz termin jej przeprowadzenia. Wykazano, że parametrem, który w największym stopniu wpływa na wzrost liczby kowenantów, jest termin przeprowadzenia emisji obligacji. Im później wprowadzano emisje na rynek, tym więcej zamieszczano w nich kowenantów. Świadczy to o narastającej w czasie świadomości inwestorów co do ryzyka zaangażowania kapitału w instrumenty dłużne poszczególnych przedsiębiorstw. Ponadto na liczbę kowenantów pozytywny wpływ ma także wielkość emitenta mierzona wartością jego aktywów ogółem. Im mniejsze przedsiębiorstwo pozyskuje kapitał dłużny na rynku, tym więcej kowenantów wprowadza do warunków emisji. Jest to zgodne z celem stosowania kowenantów jako instrumentu ograniczającego ryzyko inwestycyjne obligatariusza, które nasila się w podmiotach małych i średnich, o krótkiej historii rozwoju czy prowadzących działalność innowacyjną. Podmioty o niskiej wartości majątku mają również mniej wartościowych aktywów, które mogą pełnić funkcję zabezpieczenia długu. Nie zaobserwowano natomiast wpływu aktualnej wielkości zadłużenia emitenta i wynikającego z tego ryzyka finansowego na liczbę zastosowanych kowenantów, co może wskazywać na niechęć do dodatkowego narzucania sobie kolejnych wymogów do spełniania, które usztywniłyby strategię efektywnego zagospodarowania źródeł finansowania działalności przedsiębiorstwa.

W 2016 r. opublikowano wyniki oceny rodzajów kowenantów stosowanych przez emitentów obligacji z branży górniczej ${ }^{46}$. Przeprowadzona analiza wyka-

${ }^{44}$ N. Śmieja, M. Pauka, Analiza kowenantów w obligacjach korporacyjnych emitowanych przez niebankowe spółki z branży finansowej, „Annales Universitatis Mariae Curie-Skłodowska, Sectio H" 2013, vol. XLVII, nr 3, s. 551-561.

${ }_{45}$ N. Śmieja, M. Pauka, Zastosowanie kowenantów, op. cit., s. 399-409.

${ }^{46}$ E. Królikowska, A. Sierpińska-Sawicz, Rodzaje kowenantów, op. cit., s. 135-152. 
zała, że najbardziej doprecyzowane są kowenanty dotyczące poziomu zadłużenia emitenta, zdolności do obsługi długu oraz dysponowania przez niego posiadanym majątkiem. Stwierdzono również, że nadmierna liczba kowenantów ogranicza możliwości finansowania obligacjami programów rozwoju przedsiębiorstw, usztywnia działalność inwestycyjną emitentów, szczególnie wówczas, gdy termin wykupu emitowanych papierów dłużnych został wyznaczony na zbyt krótki okres (do trzech lat). Wówczas obligacje stają się źródłem finansowania przede wszystkim działalności operacyjnej, a nie tej ukierunkowanej na rozwój. Ponadto wykazano, że w warunkach polskich nie znajduje pełnego potwierdzenia podkreślana w literaturze zależność między rodzajem kowenantów, ich liczbą i rentownością obligacji oraz kondycją finansową emitenta. Bardziej zależność ta wynika z ryzyka branży i ryzyka makroekonomicznego, związanego $\mathrm{z}$ kształtowaniem się cyklu koniunkturalnego w gospodarce.

Poza analizą kowenantów w warunkach emisji obligacji przedsiębiorstw w ujęciu sektorowym przedmiotem zainteresowania badaczy w Polsce są również stosowane ich rodzaje. W artykule z 2016 r. przedstawiono wyniki badania kowenantów dywidendowych zawartych $\mathrm{w}$ warunkach emisji obligacji przedsiębiorstw na rynku Catalyst w latach 2009-2013 ${ }^{47}$. Wykazano, że ograniczenie ryzyka transferu wartości przedsiębiorstwa do właścicieli za pomocą groźby skorzystania przez obligatariuszy z prawa do przedterminowego żądania wykupu obligacji występuje najczęściej w formie ograniczeń w wypłacie dywidendy, a rzadziej w przeprowadzaniu skupu akcji własnych emitenta, co nie zapewnia ochrony wierzycieli przed wydrenowaniem wartości spółki. Wskazano również, że nie istnieje jakiekolwiek statystycznie istotne powiązanie między wielkością zadłużenia obligacyjnego, oferowaną inwestorom stopą zwrotu i zastosowanymi kowenantami dywidendowymi, czego należałoby się spodziewać wówczas, gdyby obligatariusze świadomie wpływali na warunki emisji, a nie je tylko przyjmowali do wiadomości czy akceptowali. Tak sprecyzowana nieefektywność rynku obligacji w Polsce może być jedną z przyczyn wzrostu ryzyka defraudacji środków kapitałowych pozyskiwanych przez emitentów, czego skutkiem jest wysoka wartość niespłacanego długu obligacyjnego pozyskiwanego na rynku Catalyst - w 2017 r. na kwotę blisko $178 \mathrm{mln}$ zł, a w 2018 r. na kwotę $142 \mathrm{mln} \mathrm{z}{ }^{48}$, co stanowi ok. 5\% wartości wszystkich obligacji przedsiębiorstw notowanych na Giełdzie Papierów Wartościowych w Warszawie.

Z wynikami kontynuacji badań $\mathrm{z}$ tego zakresu można było zapoznać się w roku $2017^{49}$. Analizie poddano rodzaje i strukturę kowenantów ograniczających transfery do właścicieli przedsiębiorstw oraz oceniono ich zróżnicowanie w zależności od cech emitentów i serii obligacji. Wykazano, że

${ }^{47}$ M. Pauka, B. Brycz, Kowenanty dywidendowe, op. cit., s. 237-248.

48 M. Sadrak, Indeks default rate, http://obligacje.pl [dostęp: 3 stycznia 2019 r.].

49 B. Brycz, M. Pauka, Ograniczenia transferów, op. cit., s. 173-183. 
pośrednie kowenanty tego typu występują w Polsce częściej niż bezpośrednie. Można $\mathrm{z}$ tego wnioskować, że emitenci obligacji w naszym kraju dążą do zapewnienia sobie możliwie największej swobody w podejmowaniu decyzji z zakresu wykorzystania pozyskanych środków dłużnych przy jednoczesnym ograniczeniu ryzyka transferów do właścicieli. Wykazano również, że z pośrednich kowenantów dywidendowych częściej korzystają przedsiębiorstwa większe i cechujące się niższym poziomem ryzyka kredytowego. Natomiast emitenci z sektora małych i średnich przedsiębiorstw oraz o wyższym ryzyku niewypłacalności preferują bezpośrednie kowenanty ograniczające transfery do właścicieli, co ma zmniejszyć swobodę działania zarządzających tą grupą podmiotów gospodarczych.

W 2018 r. pojawiła się krótka publikacja, w której przedstawiono wyniki analizy wielkości wskaźników finansowych wykorzystywanych w konstrukcji kowenantów przez wybranych emitentów obligacji przedsiębiorstw w Polsce ${ }^{50}$. Okazuje się, że najczęściej stosowanym w kowenantach wskaźnikiem oceny zdolności do spłaty długu jest relacja między długiem netto i zyskiem EBITDA. Jego teoretyczna wartość graniczna to przedział od 3,0 do 4,0, co oznacza, że generowana suma zysku z działalności operacyjnej i amortyzacji powinna pozwolić na zwrot długu w okresie od trzech do czterech lat. Za wartość normatywną przy emisjach obligacji uznaje się przedział wskaźnika od 2,0 do 3,0. Średnia wielkość tej zależności wynosi dla polskich emitentów 3,5, czyli mieści się w przyjętej normie teoretycznej. Zaobserwowano również małe rozproszenie wysokości tego wskaźnika ze względu na branżę działania emitenta czy też jego wielkość oraz wartość długu zaciągniętego na rynku.

Z kolei ze względu na specyfikę działania przedsiębiorstw z sektora deweloperskiego i handlu wierzytelnościami dominującym w kowenantach wskaźnikiem finansowym była zależność między długiem netto i kapitałem własnym. $\mathrm{W}$ drugim $\mathrm{z}$ badanych sektorów średnia wielkość tego wskaźnika była wyższa (2,5 wobec 1,0$)$, co oznacza, że spółki wierzytelnościowe w większym stopniu starają się zabezpieczać ryzyko inwestorów, nie redukując jednocześnie możliwości wykorzystania silniejszej dźwigni finansowej.

Pozostałe wskaźniki finansowe występują o wiele rzadziej, w kilku czy kilkunastu przypadkach emisji. Przykładowo, relacja EBITDA do odsetek zapisywana jest $\mathrm{w}$ kowenantach przedsiębiorstw $\mathrm{z}$ tych sektorów, które korzystają również ze wskaźnika długu netto do EBITDA, a dług netto do aktywów ogółem występuje w spółkach deweloperskich i obrotu wierzytelnościami. Inne zależności finansowe są stosowane sporadycznie, raczej jako uzupełnienie tych podstawowych.

50 A. Wiśniewski, Kowenanty - jakie wskaźniki są stosowane?, http://okiemmaklera.com. kowenanty [dostęp: 23 kwietnia 2018 r.]. 


\section{Podsumowanie}

Rynek obligacji korporacyjnych jest skutecznym obszarem pozyskiwania kapitału. Daje przedsiębiorstwom pożądaną alternatywę dostępności do środków finansowych niezbędnych do finansowania rozwoju. Oprócz kluczowych zalet długu rynkowego, jakimi są m.in. dopasowanie wielkości kapitału do potrzeb podmiotu oraz możliwość pozyskania go od zróżnicowanej grupy inwestorów, przedsiębiorstwa dostrzegły w nim szansę na sfinansowanie przedsięwzięć przy korzystniejszych warunkach finansowych niż oferowane w sektorze bankowym.

Emitenci długu korporacyjnego, dążąc do pełnego zaspokojenia własnego popytu na kapitał, powinni prowadzić działania zwiększające zainteresowanie potencjalnych inwestorów ofertą nabycia obligacji. Wśród czynników wyboru właściwej oferty kluczową rolę zaczynają pełnić kowenanty zapisywane w warunkach emisji długu. Są one w stanie w dość szerokim zakresie chronić interes inwestorów, co sprzyja emitentom w pozyskaniu wymaganej wartości kapitału.

Należy też zaznaczyć, że inwestor w podejmowaniu decyzji o alokacji kapitału nie kieruje się jedynie motywem dochodowym. Dąży również do ograniczenia ryzyka inwestycyjnego. Każdy sposób czy mechanizm służący zabezpieczeniu kapitału i osiąganych z niego korzyści, szczególnie o charakterze aktywnym, pozwalający na stałe monitorowanie sytuacji dłużnika i szybką reakcję na zaobserwowane zmiany, będzie przez inwestorów preferowany. Coraz częściej zwracają zatem oni uwagę na kowenanty zawarte w emisjach długu, traktując je jako należny przywilej za użyczenie kapitału oraz skuteczny instrument kontroli jego wykorzystania przez emitenta.

W celu zapewnienia sobie szansy na pozyskanie z rynku odpowiedniej wartości kapitału niezbędnego do pokrycia potrzeb inwestycyjnych, emitenci powinni świadomie dobierać kowenanty, uwzględniając przy tym nie tylko oczekiwania inwestorów, ale również własną sytuację finansową oraz plany wykorzystania kapitału obcego pozyskiwanego na rynku. Dobór kowenantów nie powinien być przypadkowy. Konieczna wydaje się więc standaryzacja kowenantów, których liczba, charakter i rodzaje stosowane dla danej emisji powinny zależeć od takich czynników, jak: wielkość i potencjał wzrostu emitenta, sektor jego działania, aktualna i docelowa struktura kapitału oraz aktywów przedsiębiorstwa, poziom zadłużenia, ryzyko operacyjne i finansowe, ogólna sytuacja finansowa, wysokość zapotrzebowania na kapitał, cele wykorzystania kapitału, plany rozwojowe i ryzyko ich realizacji, termin wykupu obligacji, rodzaj oferty emitowanych papierów dłużnych (prywatna czy publiczna), zabezpieczenia emisji.

Przedstawione w artykule argumenty sugerują dodatkowo, że poza wystandaryzowaniem kowenantów ważne jest również prowadzenie ciągłego i kompleksowego monitorowania sytuacji finansowej emitenta obligacji z wykorzystaniem mechanizmów ładu korporacyjnego, co wraz z właściwie dobranymi 
klauzulami umownymi zapewni pełną ochronę kapitału inwestorów, ograniczy asymetrię informacji i przyczyni się do zmniejszenia liczby naruszeń warunków emisji.

Odnosząc się wreszcie do poruszonego $\mathrm{w}$ artykule problemu konfliktu interesów między menedżerami, właścicielami i wierzycielami przedsiębiorstw, należy stwierdzić, że właściwie dobrane kowenanty pozwalają na jego ograniczenie. Zgodnie z teorią agencji można założyć, że dopóki świadczenia kompensacyjne przekraczają koszty ograniczeń nałożonych przez kowenanty, dopóty wierzyciel będzie wymagał ich zastosowania w umowach dłużnych. Przedsiębiorstwo powinno być z kolei świadome faktu, że kowenanty, obniżając koszty agencyjne oraz wysokość ryzyka działalności emitenta, oddziałują na obniżenie kosztu długu. Należy jednak pamiętać, że pogorszenie sytuacji finansowej emitenta obligacji, czego efektem stanie się niedotrzymywanie zbyt wielu lub źle dobranych kowenantów, skutkować będzie wzrostem ryzyka emitenta, żądaniem wyższych odsetek z kapitału oraz spadkiem wartości rynkowej długu. Przyczyni się to w konsekwencji do wzrostu kosztu długu. Ponadto zastosowanie wielu kowenantów w warunkach emisji oraz konieczność spełniania oczekiwań i roszczeń obligatariuszy może zmniejszać korzyści właścicieli przedsiębiorstwa. Skutkiem tego może być wzrost kosztu kapitału własnego.

\section{Bibliografia}

Achleitner A., Braun R., Hinterramskogler B., Tappeiner F., Structure and determinants of financial covenats in leveraged buyouts, „Review of Finance” 2012, vol. 16, nr 3.

Antkiewicz S., Papiery wartościowe na rynku pieniężnym i kapitałowym, CeDeWu, Warszawa 2012.

Bazzana F., Broccardo E., The role of covenants in public and private debt, 2009, https:// ssrn.com/ abstract $=1496352$.

Beatty A., Liao S., Weber J., Evidence on the determinants and economic consequences of delegated monitoring, „Journal of Accounting and Economics” 2012, vol. 53.

Bielawska A., Pawłowski M., Rynek obligacji korporacyjnych $w$ Polsce w obliczu zmian legislacyjnych. Przegląd kluczowych rozwiązań w ustawie z dn. 15 stycznia 2015 r. o obligacjach, „Kwartalnik Kolegium Ekonomiczno-Społecznego SGH. Studia i Prace" 2013, nr 3, t. 3.

Brycz B., Pauka M., Ograniczenia transferów do właścicieli w kowenantach obligacji notowanych na rynku Catalyst, „Finanse, Rynki Finansowe, Ubezpieczenia” 2017, nr 2(86).

Brycz B., Pauka M., Śmieja N., Znaczenie kowenantów na rynku obligacji korporacyjnych $w$ teorii i w badaniach empirycznych - przeglad literatury, „Zeszyty Naukowe Uniwersytetu Szczecińskiego. Finanse, Rynki Finansowe, Ubezpieczenia” 2015, nr 74(1).

Christensen H.B., Nikolaev V.V., Capital versus performance covenants in debt contracts, The University of Chicago, Booth School of Business Research Paper nr 11-06, 2011. 
Diamond D., Financial intermediation and delegated monitoring, „Review of Economic Studies" 1984, vol. 51.

Gradoń W., Emisja obligacji korporacyjnych a ryzyko uczestników rynku, „Zeszyty Naukowe Uniwersytetu Ekonomicznego w Katowicach. Studia Ekonomiczne" 2014, nr 171.

Kalay A., Dividend constraints in bond covenants, „Journal of Financial Economics” 1982, nr 10.

Konieczny Z., Obligacje przedsiębiorstw [w:] Instrumenty dtużne w gospodarce, red. I. Czechowska, CeDeWu, Warszawa 2010.

Królikowska E., Sierpińska-Sawicz A., Rodzaje kowenantów zawartych w programach emisji obligacji w spółkach węglowych, „Gospodarka Surowcami Mineralnymi” 2016, t. 32 , nr 2.

Jensen M.C., Meckling W.H., Theory of the firm: Managerial behavior, agency cost, and capital structure, „Journal of Financial Economics” 1976, nr 3(4).

Lipiec-Warzecha L., Ustawa o obligacjach. Komentarz, Wolters Kluwer, Warszawa 2010.

Moir L., Sudarsanam S., Determinants of financial covenants and pricing of debt in private debt contracts: the UK evidence, „Accounting and Business Research” 2007, vol. 37, nr 2.

Myers S.C., Determinants of corporate borrowing, "Journal of Financial Economics" 1977, nr 5.

Nash R., Netter J., Poulsen A., Determinants of contractual relations between shareholders and bondholders: Investment opportunities and restrictive covenants, „Journal of Corporate Finance" 2003, nr 9.

Niedziółka P., Zastosowanie kowenantów finansowych w bankowości korporacyjnej, „Zeszyty Naukowe Uniwersytetu Ekonomicznego w Katowicach” 2014, nr 10(934).

Park C., Monitoring and structure of debt contracts, „Journal of Finance” 2000, vol. 55.

Pauka M., Brycz B., Kowenanty dywidendowe na rynku obligacji Catalyst, „Finanse, Rynki Finansowe, Ubezpieczenia” 2016, vol. 82, nr 4.

Prewysz-Kwinto P., Catalyst - rynek obligacji GPW w 2,5 roku od otwarcia, „Annales Universitatis Mariae Curie-Skłodowska, Sectio H” 2012, vol. XLVI, nr 4.

Reisel N., On the value of restrictive covenants: Empirical investigation of public bond issues, „Journal of Corporate Finance” 2014, nr 27.

Rozwój systemu finansowego w Polsce w 2017 r., NBP, Warszawa 2018.

Sadrak M., Indeks default rate, http://obligacje.pl.

Shleifer A., Vishny R., A survey of corporate governance, „Journal of Finance”, 1997, vol. 52.

Sierpińska-Sawicz A., Bąk P., Costs of corporate bond issue in coal mining companies, „Contemporary Economics” 2016, vol. 10, nr 2.

Sierpińska M., Sierpińska-Sawicz A., Węgrzyn R., Controlling finansowy w przedsiębiorstwie, Wydawnictwo Naukowe PWN, Warszawa 2019.

Smith Jr. W., Warner J.B., On financial contracting. An analysis of bond covenants, „Journal of Financial Economics" 1979, nr 7. 
Śmieja N., Pauka M., Analiza kowenantów w obligacjach korporacyjnych emitowanych przez niebankowe spótki z branży finansowej, „Annales Universitatis Mariae Curie-Skłodowska, Sectio H” 2013, vol. XLVII, nr 3.

Śmieja N., Pauka M., Zastosowanie kowenantów w warunkach emisji obligacji - badania empiryczne wśród emitentów z branży deweloperskiej w Polsce, „Zeszyty Naukowe Uniwersytetu Szczecińskiego. Finanse, Rynki Finansowe, Ubezpieczenia” 2013, nr 62.

Wiśniewski A., Kowenanty - jakie wskaźniki sq stosowane?, http://okiemmaklera.com. kowenanty.

Wiśniewski M., Obligacje podporządkowane, wieczyste i przychodowe w Polsce - próba oceny ekonomicznych skutków nowelizacji ustawy o obligacjach, „Ruch Prawniczy, Ekonomiczny i Socjologiczny" 2016, nr 1.

\section{Akty prawne}

Rozporządzenie Parlamentu Europejskiego i Rady (UE) nr 596/2014 z 16 kwietnia 2014 r. w sprawie nadużyć na rynku oraz uchylające dyrektywę 2003/6/WE Parlamentu Europejskiego i Rady i dyrektywy Komisji 2003/124/WE, 2003/125/WE i 2004/72/WE, Dz.Urz. UE L 173 z 12 czerwca 2014 r.

Ustawa z 29 czerwca 2000 r. o zmianie ustawy o obligacjach i niektórych innych ustaw, Dz.U. nr 60, poz. 702.

Ustawa z 8 marca 2013 r. o zmianie ustawy o ofercie publicznej i warunkach wprowadzania instrumentów finansowych do zorganizowanego systemu obrotu oraz o spółkach publicznych oraz niektórych innych ustaw, Dz.U. poz. 433.

Ustawa z 15 stycznia 2015 r. o obligacjach, Dz.U. poz. 238, ze zm. 